POLITICAL DISCOURSE

УДК 325.2

Received: 05.06.2021
DOI: https://doi.org/10.26425/2309-3633-2021-9-3-137-146

Accepted: 10.09.2021

\title{
Education of migrant children as a contribution to Russia's future
}

\author{
Abubakr Kh. Rakhmonov \\ Cand. Sci. (Econ.), ORCID: https://orcid.org/0000-0001-9924-5857, Scopus Author ID: 57221330941, e-mail: Abubak.93@mail.ru \\ Institute for Demographic Research - Branch of the Federal Center of Theoretical and Applied Sociology \\ of the Russian Academy of Science, 6 k. 1, Fotieva str., Moscow, 119333, Russia
}

\begin{abstract}
The article explores the relationship between education and migration, statistics of children from migrant families in educational institutions in Russia, access to education for children from migrant families in Russia, and the integration of migrant children in schools in Russia.

Recommendations on state interaction with the children of migrants are offered. Population movements and migration processes are an integral part of human history. Another modern phenomenon, globalisation, entails fundamental changes in the world and the world market. Migration is a constant concomitant phenomenon of these changes.

Education plays a crucial role in supporting third-country migrants in adapting to a new country and culture as well as in building social relations in their host communities. Education is a key resource for participating in the economic, social, political and cultural life in today's education and knowledge society.

Experience has repeatedly shown that differences in occupational status and chances on the labour market and associated income, social welfare living standards and public reputation, as well as differences in political, social and cultural participation, are linked to differences in educational attainment.

Social integration of migrants through participation in the institutions of the host society, such as the education system and the labor market, is undoubtedly one of the most significant social problems in Russian society. For migrant children, language and structural assimilation in the education system in the sense of formal equality of opportunity are key to social integration in the host country.

The main donor countries, from which most people migrate to Russia, are primarily the CIS countries. About $30 \%$ of the total flow of migrants in Russia, finding with family and children. The birth rate among migrants is higher than local ones. Accordingly, Russia faces a big challenge, led by migrant children, from whom it can get a big contribution in the future, if they get a good education.

The main problems faced by migrant children in Russian schools are lack of knowledge of the Russian language, discrimination, refusals of enrolment, etc. The aim of the study is to examine the educational situation of migrant children in Russian schools, as well as their education as a contribution to the future of Russia.
\end{abstract}

Keywords: migration, education, children, Russia, integration, CIS, school, Russian language

For citation: Rakhmonov A.Kh. (2021). Education of migrant children as a contribution to Russia's future. Upravlenie / Management (in Russian), 9 (3), pp. 137-146. DOI: 10.26425/2309-3633-2021-9-3-137-146 
ПОЛИТИЧЕСКИЙ ДИСКУРС

Получено: 05.06.2021

Статья доработана после рецензирования: 30.08.2021

Принято: 10.09.2021

\title{
Образование детей мигрантов как вклад в будущее России
}

\author{
Рахмонов Абубакр Хасанович
}

Канд. экон. наук, ORCID: https://orcid.org/0000-0001-9924-5857, Scopus Author ID: 57221330941, e-mail: Abubak.93@mail.ru

Институт демографических исследований - обособленное подразделение Федерального научно-исследовательского социологического центра Российской академии наук, 119333, ул. Фотиевой, 6 к. 1, г. Москва, Российская Федерация

\section{Аннотация}

В статье исследованы взаимосвязь между образованием и миграцией, статистика детей из семей мигрантов в образовательных учреждениях России, доступ к образованию для детей из семей мигрантов в России, а также интеграция детей мигрантов в школы России. Предложены рекомендации по взаимодействию государства с детьми мигрантов. Движение населения и миграционные процессы - неотъемлемая часть человеческой истории. Другое современное явление, глобализация, влечет за собой фундаментальные изменения в мире и мировом рынке. Миграция - постоянное сопутствующее явление этих изменений.

Образование играет решающую роль в поддержке мигрантов из третьих стран в адаптации к новой стране и культуре, а также в построении социальных отношений в их принимающих сообществах. Образование является основным ресурсом для участия в экономической, социальной, политической и культурной жизни в современном обществе образования и знаний. Опыт неоднократно доказывает, что различия в профессиональном статусе и шансах на рынке труда и связанных с этим доходами, уровне жизни в области социального обеспечения и общественной репутации, а также различия в политическом, социальном и культурном участии связаны с различиями в уровне образования.

Социальная интеграция мигрантов через участие в институтах принимающего общества, таких как система образования и рынок труда, несомненно, является одной из наиболее значительных социальных проблем в российском обществе. Для детей-мигрантов язык и структурная ассимиляция в системе образования в смысле формального равенства возможностей являются ключом к социальной интеграции в принимающей стране.

Основными странами-донорами, из которых большинство людей мигрирует в Россию, являются в первую очередь страны СНГ. Около 30 \% от общего потока мигрантов в России находятся с семьей и детьми. Рождаемость среди мигрантов выше, чем среди местного населения. Соответственно, перед Россией стоит большая задача во главе с детьми-мигрантами, от которых она может получить большой вклад в будущем, если они получат хорошее образование.

Основными проблемами, с которыми сталкиваются дети-мигранты в русских школах, являются незнание русского языка, дискриминация, отказы в зачислении в школу и т.д. Целью исследования является изучение ситуации с образованием детей-мигрантов в российских школах, также их образования как вклада в будущее России.

Ключевые слова: миграция, образование, дети, Россия, интеграция, СНГ, школа, русский язык

Для цитирования: Рахмонов А.Х. Образование детей мигрантов как вклад в будущее России//Управление. 2021. Т. 9.

№ 3. C. 137-146. DOI: 10.26425/2309-3633-2021-9-3-137-146

() Рахмонов A.X., 2021.

Статья доступна по лицензии Creative Commons «Attribution» («Атрибуция») 4.0. всемирная

http://creativecommons.org/licenses/by/4.0/ 


\section{Introduction}

Around the world, there are impressive, exciting stories related to migration and displacement. They tell about people's aspirations, hopes, fears, expectations, ingenuity, sacrifice, courage, perseverance, success, and spiritual turmoil. These stories remind us that "migration is an expression of the search for human dignity, security, and a better future. This is an element of the social structure, our image as a human family." However, migration and displacement also serve "as a source of new borders within and between States and societies."

Education systems around the world are united by a commitment to "ensure inclusive and equitable quality education and promote lifelong learning opportunities for all" so that "no one is left behind." For all students to have the opportunity to realize their potential, these systems must meet their needs, regardless of the environment they represent. They must also meet the societal need for flexibility and adaptability to migration - a challenge facing countries with both large and small migrant populations.

About one person in 30 lives in the wrong country where they were born. Almost two-thirds of international migrants go to high-income countries [UNHCR, 2019]. Most do this in search of work, but some also for education. International migration also affects the education of their descendants. On average, one person in 80 moves within a country or crosses its border because of a conflict or natural disaster. Nine out of ten of these people live in low-and middle-income countries. Their inclusion in national education systems is essential but may be influenced by the context of such displacement.

The relevance of the problem of studying the sociocultural adaptation of migrant children is associated with the dynamic socio-psychological processes in a changing society that occur in our country.

The importance of studying the problem of adaptation of migrants to a different culture is determined by the expressed need for a well-thought-out, scientifically based state migration policy, including in the field of education, which determines the prospects for society.

\section{Research methods and sources of information}

An important methodological basis is the question of the role of children in migration studies. Migration is often interpreted by children, legitimized by taking care of them. Children become important transnational agents, as they often act as the main recipients of financial and other support, becoming an important link between the family, the educational institution, and social institutions. The article uses statistical data on the number of migrant children over several years.
The data is provided by the World Organisations for Migration, United Nations Organisations, the Federal State Statistics Service of the Russian Federation (Rosstat), the Main Directorate for Migration of the Ministry of Internal Affairs of the Russian Federation (MDM of the Ministry of Internal Affairs of the Russian Federation), etc.

\section{The relationship between education and migration}

Migration interacts with education in a complex, two-way way, affecting those who migrate, who stay, and who receive or may receive migrants (Table 1). When people at some point in their lives begin to consider the possibility of migration or go on a journey, the main determining factors include the cost of education, the need to interrupt it, the educational experience, and the result. Children who migrate from areas with lower levels of education may gain access to opportunities that they would not otherwise have. On the other hand, their knowledge and academic performance are often weaker than those of their peers in the host communities [Yankova-Brust, 2009].

Migration requires education systems to consider the needs of those who migrate and those who remain. Countries need to legally recognize the right of migrants to education and implement this right. They should adapt their education to the needs of those who lead a nomadic lifestyle [Camilla and Contini, 2014].

Education systems must be inclusive and meet their commitments to equity. Teachers should be prepared to work in classrooms with a diverse mix of students who have been traumatized by migration and especially displacement. The recognition of qualifications and previous training requires a new, modern approach to maximize the use of migrant skills that can make a significant contribution to prosperity in the long term [Christian et al, 2012].

Education, too, has a far - reaching impact on migration-both on its scale and on the way, it is perceived. It is one of the main driving factors in the decision to migrate, pushing to find a better life. It affects the attitudes of migrants, their aspirations, and the degree to which they develop a sense of belonging to their new society. The growing diversity of students in the classroom is fraught with challenges, including for residents, but it also offers opportunities to learn from other cultures, from people with different experiences. More than ever, there is a need for training programs that can combat negative attitudes in life [Janta and Harte, 2017] 
Selected examples of the relationship between education and migration

\begin{tabular}{|l|l|l|l|}
\hline \multicolumn{1}{|c|}{ Country } & Contingent & \multicolumn{1}{|c|}{ The impact of migration on education } & \multicolumn{1}{c|}{ The impact of education on migration } \\
\hline $\begin{array}{l}\text { Country } \\
\text { of origin }\end{array}$ & Migrants & $\begin{array}{l}\text { Migration leads to the problems of educating the slum } \\
\text { population } \\
\text { Education systems must adapt to the needs of populations } \\
\text { that migrate on a seasonal or recurring basis }\end{array}$ & $\begin{array}{l}\text { The probability of migration is higher among the } \\
\text { more educated individuals }\end{array}$ \\
\cline { 2 - 5 } & The remaining & $\begin{array}{l}\text { Migration leads to a decrease in the rural population and } \\
\text { complicates the provision of education } \\
\text { The transfer of funds by emigrants affects education in } \\
\text { the communities of origin } \\
\text { The absence of parents affects abandoned children } \\
\text { Emigration prospects undermine incentives to invest in } \\
\text { education } \\
\text { New programs focus on migration }\end{array}$ & $\begin{array}{l}\text { The emigration of educated persons has implications } \\
\text { for the development of affected areas, for example, } \\
\text { in the form of brain drain }\end{array}$ \\
\hline Host country & $\begin{array}{l}\text { Immigrants } \\
\text { and refugees }\end{array}$ & $\begin{array}{l}\text { The knowledge and academic performance of immigrants } \\
\text { and their children is often weaker than that of residents } \\
\text { Refugees need to be covered by national education } \\
\text { systems } \\
\text { The right of refugees to education must be ensured }\end{array}$ & $\begin{array}{l}\text { Migrants qualifications often exceed the } \\
\text { requirements set for these jobs, their skills are not } \\
\text { fully recognized or used, and their sources of } \\
\text { livelihood change } \\
\text { Internationalization of higher education encourages } \\
\text { student mobility }\end{array}$ \\
\cline { 2 - 5 } & Residents & $\begin{array}{l}\text { Classes with diverse student populations require more } \\
\text { highly qualified teachers, targeted programs to support } \\
\text { newcomers and prevent segregation, and disaggregated } \\
\text { data }\end{array}$ & $\begin{array}{l}\text { Formal and non-formal education can increase the } \\
\text { resilience of society and combat prejudice and } \\
\text { discrimination }\end{array}$ \\
\hline
\end{tabular}

Compiled by the author on the materials of the study

\section{Statistics of children from migrant families in educational institutions in Russia}

The total number of minors who have come from abroad and are living in Russia legally or illegally is unknown. Neither the Ministry of Internal Affairs nor other agencies publish information about this. According to Rosstat, in 2018, 61.3 thousand children under the age of 15 entered Russia from abroad, or $10.8 \%$ of those who arrived (Table 2). The net migration growth of children amounted to 21.9 thousand people, or $17.5 \%$ of the total increase, i.e., these are children from families that remain for a long time or forever.

For the period 2017 - 2019, the number of children under the age of 15 who left Russia was about 193 thousand people. On average, the share of migrant children under the age of 15 from the total number of migrant arrivals in Russia in the period 2017 - 2019 was $10.4 \%$.

According to A. Yakimov, an expert on the problems of ethnic minorities of the PSP-Foundation, at least $10 \%$ of foreigners who come to the Russian Federation to work take their children with them. If we consider that as of $\mathrm{Au}-$ gust 1, 2019, according to the Russian Academy of National Economy and Public Administration under the President of the Russian Federation (RANEPA) there were about 11 million temporary migrants in the country, theoretically, there may be about a million minor foreigners in Russia [Maleva, 2019].

Data on how many migrant children attend Russian schools is sketchy. According to "Komsomolskaya Pravda", in the 2018 - 2019 academic year, about 60 thousand migrant children (or $6.1 \%$ of the total number of schoolchildren in the capital) studied in Moscow schools. Similar figures were voiced by experts of the Higher School of Economics, with the clarification that the figure includes internal migrants.

In the 2017 - 2018 academic year, in the city of St. Petersburg, according to the head of the organization "Children of St. Petersburg" Yu. Alimova, the share of migrant children in the city's schools was 14.5 thousand or $3 \%$ of the total number of schoolchildren ${ }^{1}$.

The lack of official data gives rise to sharp and possibly erroneous estimates. In 2015, "Moskovskiy Komsomolets" wrote that in some Moscow schools, the share of foreign students reaches $60 \%{ }^{2}$.

According to the survey, many schools accept migrant children with the loss of $1-2$ years of education, citing poor knowledge of the Russian language or the discrepancy between the child's knowledge of school requirements, including due to significant differences in school programs in the Russian Federation and the countries from which the migrants came ${ }^{3}$.

\footnotetext{
${ }^{1}$ Children of St. Petersburg. Available at: https://detipeterburga.ru/ (accessed 25.04.2021).

${ }^{2}$ Balabas E. The number of migrant children in the capital's schools reaches $60 \%$, Moskovskiy komsomolets. Available at: https://www.mk.ru/ social/2015/12/14/chislo-detey-migrantov-v-stolichnykh-shkolakh-dokhoditdo-60.html (accessed 25.04.2021).

${ }^{3}$ Russia: Thanks to the children of migrants, schools are improving statistics, Azattyk. Available at: https://kloop.kg/blog/2019/01/14/rossiyablagodarya-detyam-migrantov-shkoly-uluchshayut-statistiku/ (accessed 26.04.2021).
} 
Statistics of arrived migrants and children of migrants under the age of 15 in Russia for 2017-2019

\begin{tabular}{|c|c|c|c|}
\hline Year & Total arrived migrants, thousand & $\begin{array}{c}\text { Children of migrants aged 0-15 } \\
\text { pers. }\end{array}$ & $\begin{array}{c}\text { The share of children 0-15 years } \\
\text { old from the total number } \\
\text { of arrived migrants, \% }\end{array}$ \\
\hline 2017 & 589.0 & 63.7 & 10.8 \\
2018 & 565.7 & 61.3 & 10.8 \\
\hline
\end{tabular}

Source $^{4}$

\section{Access to education for children from migrant families in Russia: legislation and the scale of the problems}

In accordance with Article 62 of the Constitution of the Russian Federation, foreign citizens and stateless persons in the Russian Federation are endowed with rights and obligations on an equal basis with citizens of Russia. Article 78 of the Law "On Education in the Russian Federation" gives foreign citizens and stateless persons the right to receive education [Minaeva et al, 2019].

Officially, all school-age children living and staying in the territory of the Russian Federation have equal access to school education in Russia. This is guaranteed by the Constitution of the Russian Federation, the law "On Education", the Convention on the Rights of the Child, as well as various resolutions of regional authorities that determine the procedure for children's access to educational institutions in a particular subject of the Federation - for Moscow, for example, this is the decision of the Board of the Department of Education of the City of Moscow, dated December 22, 2005, No. 19/1 "On the integration of children of foreign migrants into the educational environment of the city of Moscow". When admitting children to school, only the child's birth certificate, the passport of one of the parents and the medical card (with the results of the medical examination and vaccination, according to the age of the child) must be presented. The legal status of parents and the presence or absence of registration should not affect the admission of children to school in any way [Minaeva et al, 2019].

The main problems faced by migrant children in Russian schools are the lack of knowledge of the Russian language, discrimination, refusals to enroll in school, etc.

\section{Lack of knowledge of the Russian language}

It is good if the family moves before the child goes to the first grade. So, there is an opportunity to gain vocabulary on playgrounds. But the language can be dif-

\footnotetext{
${ }^{4}$ Federal State Statistics Service of the Russian Federation (Rosstat). Available at: https://rosstat.gov.ru(accessed 25.04.2021).
}

ficult in many cases - after all, at home in the family they speak their native language even after moving to Russia. And at school and with new friends, you need to use Russian. Because of stress, a child can be silent at school for months without understanding anything ${ }^{5}$.

\section{Discrimination}

Migrants in Russian schools are sometimes forced to face bullying. In Russia, in principle, the so-called domestic nationalism is widespread - what are the illegal wording in the ads for the delivery of apartments: "I will rent exclusively to persons of Slavic nationality." 6

Society tends to perceive people with migration experience as "terrorists". In everyday life, a lot of offensive and rude name-calling, which are thrown at visitors.

Russian-speaking children often absorb this with culture, repeating after adults and picking up what they hear on the street. It is not surprising that in a conflict with a migrant child, insults of nationality will be used. ${ }^{7}$

\section{Refusal of admission to the school}

The work of schools with migrants often begins with the fact that parents who are trying to arrange children in an educational institution require Russian registration at the place of residence. This is an illegal requirement. It contradicts Article 43 of the Constitution.

Often, new arrivals do not have registration, and Russian schools automatically register children as "illegal immigrants", although they may have a package of necessary documents that confirm the legality of their stay in Russia. But people who have a poor command

\footnotetext{
${ }^{5}$ Ivanyushina V. Research on migrant children in schools. Available at: https://slon.hse.ru/issledovanija-detej-migrantov-v-shkolax (accessed 26.04.2021).

6 Trushina E. School bullying: why some children bully others and how to protect your child from violence. Available at: https://externat.foxford.ru/ polezno-znat/shkolnyy-bulling (accessed 30.04.2021).

${ }^{7}$ Russia: Thanks to the children of migrants, schools improve statistics, Azattyk. Available at: https://kloop.kg/blog/2019/01/14/rossiya-blagodaryadetyam-migrantov-shkoly-uluchshayut-statistiku/ (accessed 30.04.2021).
} 
of the Russian language, it is awkward to argue and try to defend their rights. ${ }^{8}$

In addition, the legislation requires that foreigners who have not received a residence permit or a temporary residence permit leave the country after three months. Therefore, many migrants cross the border and return several times a year, making their studies inconsistent.

\section{Integration of migrant children in Russian schools}

Visiting children experience stress - they had to leave all their previous lives, friends, and traditions in their native country [Genka Yankova-Brust, 2019]. Here in Russia, children are forced to join a new, unfamiliar society. When people emigrate, they simultaneously strive to preserve their own traditions and adapt to the local way of life and the norm of behavior. Children often need the qualified help of adults-psychologists and teachers.

The integration of migrant children into a new environment is becoming one of the primary tasks facing the education system [Hans-Peter et al, 2016]. The main problems that arise while solving this problem are as follows.

First, migrant children often have difficulty communicating with their classmates. First, the lack of development of communication skills in primary school children - both indigenous people and migrants-hinders this. ${ }^{9}$ For example, many children at the time of entering primary school do not know how to get acquainted with their peers, do not know how to politely address another child, how to politely refuse. In addition, the interaction skills that migrant children come to school with are often inadequate in the new social environment: visiting children may find offensive words and expressions that are not such in the local children's culture. Culturally determined differences in the ways of nonverbal communication, norms of relations, values, standards, and rituals of behavior are numerous, and they often cause unpleasant misunderstandings when interacting with children of different nationalities. In addition, many migrant children do not speak Russian very well, which creates additional difficulties for communication and mutual understanding [Zasypkin et al, 2013].

Secondly, migrant children are often given a difficult school curriculum, which reduces their self-esteem, negatively affects relationships with others, and almost automatically reduces the social status of the child among

\footnotetext{
${ }^{8}$ What is it like for migrants to study in Russia? Available at: https:// externat.foxford.ru/polezno-znat/deti-migrantov-v-rossijskih-shkolah (accessed 30.04.2021).

${ }^{9}$ Ivanyushina V. Research on migrant children in schools. Available at: https://slon.hse.ru/issledovanija-detej-migrantov-v-shkolax (accessed 26.04.2021).
}

classmates. The usual reasons for the poor performance of migrant children are poor knowledge of the Russian language and poor preschool education. They do not always understand the teacher's explanations, they do not know how to express their thoughts [Kasenova et al, 2020].

As a result of the combined effect of these factors, many migrant children, even at the age of seven or eight, begin to perceive the society in which they are forced to be, as rejecting, humiliating, and discriminating. ${ }^{10}$ The solution to this problem is to purposefully teach younger students to interact and cooperate directly in class groups. It is necessary to teach children to interact and cooperate immediately after their appearance in school: this is the best way to avoid the formation and consolidation of negative stereotypes, including ethnic ones. The focus should be on the formation of children's friendly attitude to others, readiness to discuss problem situations and the ability to find constructive solutions. To do this, the teacher must determine the way the children's work is organized. The subject of classes can be any: for example, drawing, designing, creating texts, etc. This makes it possible to solve other educational tasks simultaneously with teaching children to cooperate. Thus, there is no need to introduce additional training hours or change the content of the training plans [Zborovsky and Shuklina, 2013].

In Europe-for example, France or Germany-there are so-called "welcome classes". A school for migrants should create conditions to help newly arrived children integrate into a new social environment and find themselves in an unfamiliar society [Manzoni and Rolfe, 2019]. In Russia, there are still few such programs, and these are more private commercial initiatives that not every visitor can afford.

Another troubles which will face the migrant children during integration in Russian schools are adult children (13 - 14 years old) who came with their parents to Russia and do not know Russian language.According to the leading expert of the Higher School of Economics (HSE) Institute of Education Nadezhda Bysik: "In primary school, a child who does not speak Russian does not need a separate adaptation at all, he immediately joins the regular class and, as a rule, quickly learns a new language. But if a child is $13-14$ years old and does not know the language, they cannot be put in a class with their peers and they lose at least a year of training." 11

\footnotetext{
${ }^{10}$ What is it like for migrants to study in Russia? Available at: https:// externat.foxford.ru/polezno-znat/deti-migrantov-v-rossijskih-shkolah (accessed 30.04.2021).

${ }^{11}$ Kozhanova E. Researchers for the first time have counted the number of migrant children in Russian schools, Komsomolskaya pravda. Available at: https://www.kp.ru/daily/26926.4/3973119/ (accessed 25.04.2021).
} 
In Russia, due to the lack of extracurricular programs, helping children of migrants in adaptation, some diasporas of the Commonwealth of Independent States (CIS) countries themselves are forced to create such programs for the children of their compatriots. For example, Kyrgyz Club studying the Russian language "Bilim". They play football with children and develop their artistic skills. Through art and sports, children go through a difficult period of habituation.

The trouble is that no one in Russia works with migrant families. If they come to school, the school sighs and accepts them. But no one even knows how many migrant children do not attend school and are not adapted to life in Russia at all. ${ }^{12}$

\section{The contribution of educated migrant- children to the future of Russia}

\section{Highly qualified specialists}

Highly qualified migrants are becoming an important resource for innovative development, for which developed countries are currently fighting among themselves. At the same time, the need to compete in the conditions of the constant strengthening of the "global race for talent" is a challenge for states.

The economic situation in Russia is such that it needs an inflow of migrants, but not so much workers as skilled ones.

According to the experts of the Hays Global Skills Index, there is a growing shortage of highly qualified personnel in Russia. According to their opinion: "It is expected that the increase in the retirement age will reduce the shortage of specialists to some extent and in the short term will ease the pressure on the labor market. However, to solve this problem in the long term, educational institutions and employers will have to significantly revise training and motivation programs aimed at developing qualified specialists." 13

The shortage of specialists in Russia may reach 2.8 million people by $2030 .{ }^{14}$ The losses of the Russian economy

\footnotetext{
12 Ovsyannikov I. Russia: it is difficult for migrant children to get an education and socialize. Available at: https://russian.eurasianet.org/россиядетям-мигрантов-сложно-получить-образование-и-социализироваться (accessed 25.04.2021).

${ }^{13}$ Alikin A. There is a growing shortage of highly qualified specialists in Russia, EurasianNet. Available at: https://russian.eurasianet. org/в-россии-растет-дефицит-высококвалифицированных-специалистов (accessed 25.04.2021).

${ }^{14}$ Grishin N., and Romanova S. The shortage of specialists in Russia will reach 2.8 million people by 2030, RBC. Available at: https://www.rbc.ru/rb cfreenews/5af06b549a79472ff921935e (accessed 27.04.2021).
}

in this regard are estimated at about 300 billion US dollars. ${ }^{15}$

Accordingly, due to the education of migrant children, Russia will receive new highly qualified specialists and can cover this deficit in its labor market. And it's over, it will also make a great contribution to the Russian economy.

\section{Demographic crisis}

The current difficult demographic situation is such that Russia needs migrants. But the main flows of migrants in Russia come from the Commonwealth of Independent States (CIS) countries, and unfortunately the visa-free regime allows them to migrate most often seasonally, that is, without the intention to stay in Russia for a long-term period.

After the collapse of the USSR and the independence of Russia ${ }^{16}$, according to the World Bank, the population of Russia in 1991 amounted to 148.4 million people. ${ }^{17}$ In 2008, the population of Russia decreased to 142.7 million people, compared to 1991, it decreased by $5.7 \mathrm{mil}-$ lion people (up to $4 \%$ ). In 2020, the population of Russia was 144.1 million people, 4.3 million people less than in $1991 .{ }^{18}$ Every year, in Russia, the birth rate decreases, and the death rate increases. And one of the ways out of this crisis is migrants. As we have noted, migrants from the Commonwealth of Independent States (CIS) countries in Russia are most often of a short-term nature, but due to the education of migrant children, it is possible to increase the demography of Russia. As practice shows, after receiving an education in Russia, most often migrant-children do not go to the country of origin, but find a job, and stay in the Russian Federation. Accordingly, due to these children, the demography of Russia will also increase.

\section{Reducing the crime rate in Russia}

Due to the education of migrant children, it is possible to reduce the level of illegal migrants and the level of crime on the part of migrants in Russia.

In 2019, 15.7 million foreign citizens came to Russia, and the number of crimes of visitors amounted to $38,563 .{ }^{19}$

\footnotetext{
${ }^{15}$ Grishin N., and Romanova S. The shortage of specialists in Russia will reach 2.8 million people by 2030, RBC. Available at: https://www.rbc.ru/rb cfreenews/5af06b549a79472ff921935e (accessed 27.04.2021).

${ }^{16}$ The collapse of the USSR, World History. Available at: https:// w.histrf.ru/articles/article/show/raspad_sssr_n (accessed 27.04.2021).

${ }^{17}$ World Bank Data. Available at: https://databank.worldbank.org/ source/world-development-indicators (accessed 27.04.2021).

${ }^{18}$ World Bank Data. Available at: https://databank.worldbank.org/ source/world-development-indicators (accessed 27.04.2021).

${ }^{19}$ Tretyakova M. The Ministry of Internal Affairs revealed the crime rate among migrants, Parlamentskaya gazeta. Available at: https:// www.pnp.ru/social/v-mvd-raskryli-uroven-prestupnosti-sredi-migrantov. html (accessed 27.04.2021).
} 
In 2018, about 16.3 million citizens of other countries arrived in the country, the number of crimes for that year was $42,676 .{ }^{20}$ According to the Ministry of Internal Affairs of Russia, the number of crimes committed by migrants in Russia in January, 2021 increased by $6.1 \%$ compared to the same period last year. ${ }^{21}$

A comparison of these data with the indicators of previous years suggests that in recent years, crime among migrants has increased.

Accordingly, based on our research, we can confidently say that the education of migrant-children plays a big role in the Russian economy, demography, politics, culture, etc.

\section{The author's recommendation on the interaction of the state with the children of migrants}

Laws and policies regarding migrant children need to be simplified

Laws and policies currently do not apply to migrant children, denying their rights and ignoring their needs. Migrants are among the most vulnerable people in Russia, and include seasonal migrants looking for an opportunity to earn money, and children detained for violating immigration rules. At the same time, they are often openly denied the opportunity to enter a school that could provide them with a safe environment and give them hope for a better future.

\section{Should not be indifferent to the education of migrants}

Indifference to the education of migrants leads to the fact that many opportunities in the field of human potential are missed. Sometimes problems with paperwork, lack of data, or bureaucratic and uncoordinated systems cause many people to be unable to overcome administrative obstacles. Nevertheless, investing in the education of gifted and motivated migrants can boost development and economic growth, not only in their host countries, but also in their countries of origin.

\section{Educational environment}

Providing educational opportunities is not enough in itself. The school environment must be adapted to meet the specific needs of those who are constantly migrating. Their admission to the same schools as the host population is the first step towards social cohesion. However,

\footnotetext{
${ }^{20}$ Tretyakova M. The Ministry of Internal Affairs revealed the crime rate among migrants, Parlamentskaya gazeta. Available at: https://www. pnp.ru/social/v-mvd-raskryli-uroven-prestupnosti-sredi-migrantov.html (accessed 27.04.2021).

${ }^{21}$ The Ministry of Internal Affairs of Russia. Available at: https://мвд. pф/reports/item/23163626/ (accessed 27.04.2021).
}

the nature and language of teaching, as well as discrimination, can deter them.

\section{Support for teachers}

Highly qualified teachers play a vital role in ensuring an inclusive approach to migrant and refugee children, but they themselves need support to cope in classrooms with a multilingual, multicultural composition of students, some of whom require socio-psychological assistance.

\section{Curriculum}

A well-designed curriculum that encourages diversity, provides essential skills, and combats prejudice is also essential, while also having a beneficial impact outside of school. However, textbooks sometimes include outdated descriptions of migration and undermine efforts to achieve inclusivity. Many training programs also lack the flexibility to accommodate the lifestyle of those who are constantly migrating.

\section{Results}

Education plays a crucial role in supporting thirdcountry migrants to adapt to their new country and culture, as well as in building social relationships in their host communities. Education is the main resource for participation in economic, social, political, and cultural life in the modern society of education and knowledge. ${ }^{22}$

According to Rosstat, in 2018, 61.3 thousand children under the age of 15 entered Russia from abroad, or $10.8 \%$ of those who arrived. The net migration growth of children amounted to 21.9 thousand people, or $17.5 \%$ of the total increase, i.e., these are children from families that remain for a long time or forever.

The main problems faced by migrant children in Russian schools are the lack of knowledge of the Russian language, discrimination, refusals to enroll in school, etc.

Visiting children experience stress - they had to leave all their previous lives, friends, and traditions in their native country. Here in Russia, children are forced to join a new, unfamiliar society. When people emigrate, they simultaneously strive to preserve their own traditions and adapt to the local way of life and the norm of behavior. Children often need the qualified help of adultspsychologists and teachers.

The integration of migrant children into a new environment is becoming one of the primary tasks facing the education system. The trouble is that no one in Russia works with migrant families. If they come to school, the school sighs and accepts them. But no one even

\footnotetext{
22 Balandina A. Direct threat to the economy: why migrants are not taken to Russian schools. Available at: https://www.gazeta.ru/ social/2021/04/08/13551464.shtml (accessed 27.04.2021).
} 
knows how many migrant children do not attend school and are not adapted to life in Russia at all.

Getting a high-quality education for migrant children is not only a contribution to their future, but also to the future of Russia since the education of migrant children is the future of highly qualified specialists in Russia.

Accordingly, based on our research, we can confidently say that the education of migrant-children plays a big role in the Russian economy, demography, politics, culture, etc.

\section{Conclusion}

Migration is characterized by both order and disorder. Societies most often seek to regulate the movement of the masses of people but may face unpredictable inflows of migrants. Such movements may lead to the emergence of new dividing lines, but they can also provide clear advantages, both to the countries of origin of migrants and to the countries receiving them [Nusche, 2019].

Migration flows are based on will and compulsion. Some set out on their own initiative in search of opportunities for work and study, while others are forced to flee from persecution and the dangers to which their sources of livelihood are exposed. Host communities and politicians can have endless debates about whether these newcomers are oppressed or not oppressed, whether they are legally here or illegally, whether they are valuable or dangerous, whether their presence is a benefit or a burden [Schneeweis, 2011].

The problem of increasing the number of migrants from other countries in Russian society, primarily from the former Soviet republics of Central Asia and the Caucasus, has recently become more and more urgent.
Once in a foreign country, migrants, along with their place of residence, are forced to change their way of life, the language of communication outside the family, to adapt to a different worldview, to the need to interact with people of a different culture. In society, there are such social phenomena as xenophobia (dislike of everything foreign, alien in spirit, views, interests, traditions, external features) and migrant phobia (fear of immigrants from other countries encroaching on the places of work, residence, etc. of the main population). The large migration to Russia in recent years has caused discontent among many Russians, which has affected their attitude not only to the migrants themselves, but also to their children. In such circumstances, special attention should be paid to the problem of the entry of migrant children who become Russian citizens into new social, cultural, pedagogical, and other conditions.

The State should make efforts to include the younger generation of migrants in the education system. The imperfection of the system, bureaucratic difficulties, and often xenophobia led to the fact that children are not accepted into educational institutions, creating for them, as well as for society, the ground for future problems. Education builds skills in migrant children that enable them to become successful in life, and, consequently, to receive higher incomes, which will give them a chance to break out of the circle of chronic poverty. Of course, getting a high-quality education for migrant children is not only a contribution to their future, but also to the future of Russia since the education of migrant children is the future of highly qualified specialists in Russia.

\section{References}

UNHCR (2019), Access to education for refugee and migrant children in Europe, UNHCR, $16 \mathrm{p}$.

Blossfeld Hans-Peter, Wilfried Bos, Daniel Hans-Dieter, Hannover Bettina, Köller Olaf, Lenzen Dieter, Roßbach Hans-Günther, Seidel Tina, Tippelt Rudolf, and Wößmann Ludger (2016), Integration through education. Migrants and refugees in Germany (Integration durch Bildung. Migranten und Flüchtlinge in Deutschland), Waxmann Verlag GmbH, Münster, Germany, 169 p. (In German).

Camilla B., and Contini D. (2014), “Migrant achievement penalties in Western Europe: Do educational systems matter?”, European Sociological Review, vol. 30, issue 5, pp. 670-683. https://doi.org/10.1093/esr/jcu067

Dustmann Ch., Frattini T., and Lanzara G. (2011), "Educational achievement of second-generation immigrants: an international comparison", Economic Policy, no. 27 (69), pp. 143-185. https://doi.org/10.2139/ssrn.1991148

Genka Yankova-Brust (2009), Education and demand of migrant children at German schools (Bildung und Förderung von Migranten kindern an Deutschen Schulen), GRIN Verlag, Philipps-Universität, Marburg, München, Germany, 14 p. (In German).

Janta B., and Harte E. (2017), Education of migrant children, EC, 37 p.

Manzoni Ch., and Rolfe H. (2019), How schools are integrating new migrant pupils and their families, National Institute of Economic and Social Research, 106 p. https://doi.org/10.13140/RG.2.2.19657.80488

Kasenova N.N., Musatova O.V., Dzhurabaeva G.K., Kergilova N.V., Orlova R.A., Podzorova S.V., and Ushakova E. V. (2020), Work with migrant children at educational organizations, Educational and methodological manual, Ministry of Science and Higher 
Education of the Russian Federation, Novosibirsk State Pedagogical University, Novosibirsk Regional Public Organization "Uzbek-Russian National-Cultural Center”, Publishing house of NSPU, Novosibirsk, Russia, 198 p. (In Russian).

Minaeva E.I., Polyntseva I.N., and Kulikova O.P. (2019), Creating conditions for socialization and adaptation of migrant children: methodological recommendations, authors-comp., under the general edition of Minaeva E. I, Autonomous Institution of Additional Professional Education of the Khanty-Mansiysk Autonomous Okrug-Ugra "Institute of Education Development", Institute of Education Development, Khanty-Mansiysk, Russia, 72 p. (In Russian).

Monthly Monitoring of the Socio-Economic Situation and Health of the Population: 2015 - August 2019 (2019), Russian Academy of National Economy and Public Administration under the President of the Russian Federation, edited by T. M. Maleva, Moscow, Russia, 53 p. (In Russian).

Nusche D. (2009), "What works in migrant education? A review of evidence and policy options", OECD, no. 22 , 49 p.

Schneeweis N. (2011), "Educational institutions and the integration of migrants", Journal of Population Economics, vol. 24, no. 4, pp. 1281-1308. https://doi.org/10.1007/s00148-009-0271-6

Zasypkin V.P., Zborovsky G.E., and Shuklina E.A. (2013), "Training of children migrants as the socially-pedagogical problem", Pedagogical Journal of Bashkortostan, no. 2 (45), pp. 35-51. (In Russian).

Zborovsky G. E., and Shuklina E. A. (2013), "Education of migrant children as a problem of their social adaptation", Sociological Studies, no. 2, pp. 80-91. (In Russian). 